\title{
Chemical constituents of Piptadenia gonoacantha (Mart.) J.F. Macbr (pau jacaré)
}

\author{
MÁRIO G. DE CARVALHO ${ }^{1}$, MARITZa A.R. CARDOZO ${ }^{1}$, \\ FRANCISCO E.A. CATUNDA JUNIOR ${ }^{1}$ and ACÁCIO G. DE CARVALHO ${ }^{2}$ \\ ${ }^{1}$ Departamento de Química, ICE, Universidade Federal Rural do Rio de Janeiro \\ BR 465, km 07, 23890-000 Serópedica, RJ, Brasil \\ ${ }^{2}$ Departamento de Produtos Florestais, Instituto de Florestas, Universidade Federal Rural do Rio de Janeiro \\ BR 465, km 07, 23890-000 Seropédica, RJ, Brasil
}

Manuscript received on February 4, 2009; accepted for publication on November 24, 2009

\begin{abstract}
The phytochemical investigation of Piptadenia gonoacantha (Mart.) J.F. Macbr. (Leguminosae-Mimosoideae), commonly known as "pau jacaré" (alligator stick), afforded sitosterol, campesterol, stigmasterol, the N-benzoylphenylalanine-2-benzoylamide-3-phenylpropyl ester, known as asperphenamate, sitosterol-3-O- $\beta$-D-glucopyranoside, besides three flavonoids, apigenin, 5-O-methylapigenin and 7,4'-dihydroxy-3',5-dimethoxyflavone from its branches. From its leaves, the methyl gallate and two flavonoids, vitexin and isovitexin, were isolated. From its bark, a mixture of sitosterol, campesterol, and stigmasterol, besides a mixture of cycloartenone, cycloartan-25-en-3-one, and 24-methylene-cycloartenone, and the pure triterpenes 24-methylenecycloartanol, friedelin, lupeol and lupenone, were isolated. Their structures were established on the basis of spectral analysis, comparison with literature data and GC-MS analysis of the mixtures. The ester, flavonoids and the cycloartanes are been identified for first time in the genus Piptadenia.
\end{abstract}

Key words: Leguminoseae, Piptadenia gonoacantha, terpenoids, asperphenamate, flavonoids, "pau jacaré".

\section{INTRODUCTION}

The Piptadenia genus belong to Mimosoideae (Leguminosae) and have about 80 tropical species frequently occurring in South America. The Piptadenia species are known in Brazil as angico, and as cebil in Argentina and Paraguay. These species have been used in tannery due to the tannins, in building due to the hard and heavy wood and in the recovery of forests because they can grow in poor and degraded soil (Lorenzi 1998, Correa 1984). The scientific interest on Piptadenia species is motivated by their use in snuff preparation, such as $P$. peregrina that causes humans euphoria due to the indole alkaloid from its seeds (Stromberg 1954). More frequently, indole alkaloids, such as bufotenine and derivatives, have

Correspondence to: Mário Geraldo de Carvalho

E-mail: mgeraldo@ufrrj.br been detected by the phytochemical and pharmacological studies of Piptadenia to justify its popular use because of its psicotropic and alucinogenic properties (e.g. P. colubrine (Patcher et al. 1959), P. falcate (Giesbrecht 1960), P. macrocarpa (Legler and Tschescher 1963)). The more recent study of other parts of species of this genus did not detect alkaloids, only flavonoids such as the anadantoside (Piacente et al. 1999), cumarine, triterpene, steroids and flavonoids (Miyauchi et al. 1976) from $P$. macrocarpa. Flavonoids, chalcone, two benzoil derivatives, sitosterol, lupeol and betuline, were identified in the woods extract from P. rigida (M.S. Gomes, unpublished data, Nascimento et al. 2003). The Piptadenia gonoacantha is a tree that occurs in the South and Southeast Brazil, including Mato Grosso do Sul and the Atlantic complex. It is easily identified in the forest 
due to its salience in the bark like lamina, and owed to it the tree is named as "icarapé", "caniveteiro", "cascode-jacaré" and mainly as "pau jacaré" (alligator stick) (Fig. 1). This is the first phytochemical study of $P$. gonoacantha in which we describe the presence of three cicloartenones, cicloartanol, three steroids, sitosterol-3-O- $\beta$-D-glycopiranoside, three pentaciclic triterpenes, methyl gallate, the ester asperphenamate, and five flavonoids, apigenin, apigenin-5-methyl ether, 7,4'-dihydroxy-3',5-dimethoxyflavone, vitexin and isovitexin (Fig. 2).
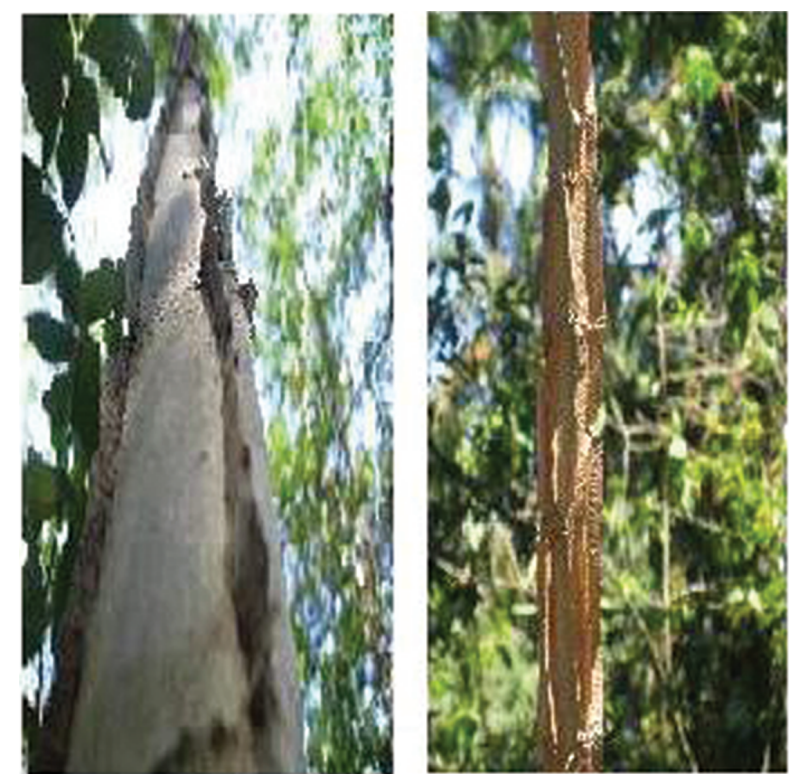

Fig. 1 - Stalk aspect of Piptadenia gonoacantha, "pau-jacaré".

\section{MATERIALS AND METHODS}

General Experimental Procedure

Melting points have not been corrected. IR spectra were recorded on a Perkin-Elmer 1605 FT-IT spectrophotometer using $\mathrm{KBr}$ for solids and film for liquid samples (range 4000-600 $\mathrm{cm}^{-1}$ ). ${ }^{1} \mathrm{H}$ and ${ }^{13} \mathrm{C}$ NMR spectra (including $1 \mathrm{D}$ and $2 \mathrm{D}$ specials techniques) were recorded on a Brüker AC-200 $\left({ }^{1} \mathrm{H}\right.$ : 200 and $\left.{ }^{13} \mathrm{C}: 50 \mathrm{MHz}\right)$ of UFRRJ, and Brücker DRX-500 $\left({ }^{1} \mathrm{H}: 500\right.$ and ${ }^{13} \mathrm{C}: 125$ MHz) of UFC. DMSO- $\mathrm{d}_{6}, \mathrm{CD}_{3} \mathrm{OD}$ or $\mathrm{CDCl}_{3}$ with TMS as internal standard were used as solvents. Bruker Ac200 was used in the NOEDIFF experiments. LRMS were recorded on Varian saturn 2000 instrument with ion trap at $70 \mathrm{eV}$ and electron ionization. The Chromatography columns were packed with silica gel (Vetec and Aldrich 0.05-0.20 mm) and Sephadex LH-20 (Sigma, USA); silica gel F254 G (Vetec) was used for preparative TLC; aluminum backed (Sorbent) silica gel plates W/UV254 were used for analytical TLC, with visualization under UV (254 and $366 \mathrm{~nm}$ ), with $\mathrm{AlCl}_{3}$-ETOH (1\%), Lieberman-Burchard and/or Godin reagents, or exposure to iodine vapor.

Plant MATERiAL

The branches and leaves of Piptadenia gonoacantha (Mart.) J.F. Macbr (Fig. 1) were collected in UFRRJ Campus, Seropédica, Rio de Janeiro, Brazil, in 2005 by Professor Acácio Geraldo de Carvalho. A voucher specimen (RBR 6939) has been deposited at RBR Herbarium, Instituto de Biologia, UFRRJ.

\section{EXTRACTION AND ISOLATION}

The powdered branches (1448 g) and leaves $(560 \mathrm{~g})$ of Piptadenia gonoacantha were extracted with methanol at room temperature. The solvent was removed under vacuum to yield the residues PGBrM (46.4 g) and PGLM $(19.7 \mathrm{~g})$, respectively. The bark $(650.0 \mathrm{~g})$ was extracted with dichlorometane and methanol, and the residues PGBaD $(5.0 \mathrm{~g})$ and PGBaM $(70 \mathrm{~g})$ were obtained. The residue PGBrM (40.4 g) was partitioned into $\mathrm{CHCl}_{3}$, ethyl acetate, and methanol: $\mathrm{H}_{2} \mathrm{O}(9: 1)$ to yield fractions PGBrMC (4.0 g), PGBrMA (4.5 g), and PGBrMM (24.3 g), respectively. Fraction PGBrMC was chromatographed on a silica gel column eluting initially with $\mathrm{CHCl}_{3}$ and gradually increasing the polarity with $\mathrm{MeOH}$ to give 35 subfractions. The fractions PGBrMC-6-7, after recrystallization from $\mathrm{MeOH}$, afforded a solid composed by the mixture of $\mathbf{4 , 5}$ and $\mathbf{6}$. The subfraction PGBrMC-2-11 was further purified by CC eluted with $\mathrm{CHCl}_{3} 100 \%$ to obtain $\mathbf{1 0}$ (31.0 mg). Subfraction PGBrMC-16-20 was further purified by crystallization from methanol to afford 4a $(37.2 \mathrm{mg})$. Fraction PGBrMA was subjected to silica gel CC eluting with $\mathrm{CHCl}_{3}: \mathrm{MeOH}$ and increasing the polarity with $\mathrm{MeOH}(100 \%)$ to obtain 33 subfractions. Fractions PGBrMA-6-7 was purified in silica gel CC eluting with $\mathrm{CHCl}_{3}: \mathrm{MeOH}(9: 1)$ to afford 10 subfractions. Fraction PGBrMA-6-7/4 was applied to a Sephadex LH-20 gel column, eluting with $\mathrm{CHCl}_{3}: \mathrm{MeOH}(7: 3)$ to afford a yellow solid $\mathbf{1 1}(6.0 \mathrm{mg})$. 


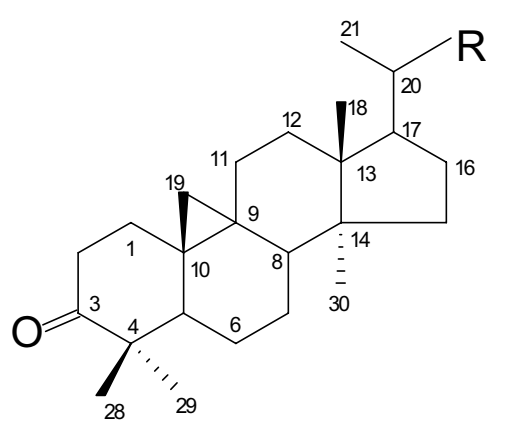

1: $\mathrm{R}=$

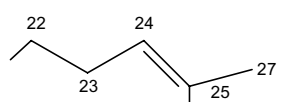

2: $\mathrm{R}=$<smiles>CCCCC</smiles>
26

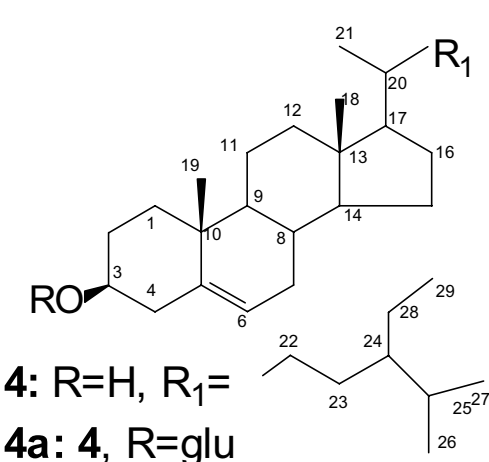

4a: 4, R=glu

5: $\mathrm{R}=\mathrm{H}, \mathrm{R}_{1}=$ $\widehat{22}_{24}^{23} \overbrace{\left.\right|_{26} ^{25}}^{28} 27$ 6: $\mathrm{R}=\mathrm{H}, \mathrm{R}_{1}=\overbrace{23}^{22} \sqrt[28]{2_{25}^{29}}$

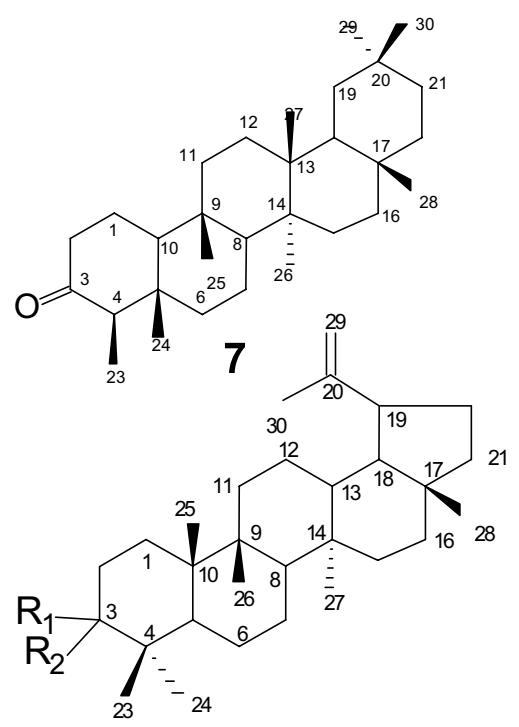

8: $\mathrm{R}_{1}, \mathrm{R}_{2}=\mathrm{O}$

9: $\mathrm{R}_{1}=\mathrm{OH}, \mathrm{R}_{2}=\mathrm{H}$

3a: 3 with $3-\mathrm{OH}$

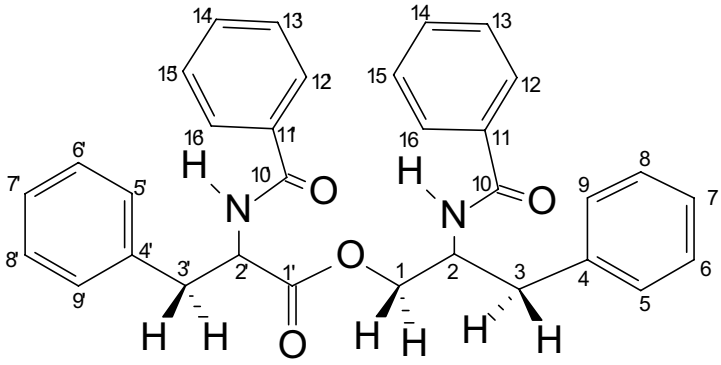

10<smiles>[R]c1cc(-c2cc(=O)c3c([R])cc(O)cc3o2)ccc1O</smiles>

11: $\mathrm{R}_{1}=\mathrm{OH}, \mathrm{R}_{2}=\mathrm{H}^{5}$

12: $\mathrm{R}_{1}=\mathrm{OCH}_{3}, \mathrm{R}_{2}=\mathrm{H}$

13: $\mathrm{R}_{1}=\mathrm{R}_{2}=\mathrm{OCH}_{3}$<smiles>[R]Oc1ccc(-c2cc(=O)c3c(O[R7])c([R3])c([R2])c([R2])c3o2)cc1</smiles>

14: $R_{1}=R_{3}=H, R_{2}=$ glu

14a: $R_{1}=M e, R_{3}=H, R_{2}=$ glu 15: $R_{1}=R_{2}=H, R_{3}=$ glu,<smiles>[R]Oc1cc(C(=O)OC)cc([R])c1[R]</smiles>

16: $\mathrm{R}=\mathrm{H}$

16a: $\mathrm{R}=\mathrm{CH}_{3}$

Fig. 2 - Structures of compounds isolated from Piptadenia gonoacantha, "pau jacaré". 
Fraction PGGMA-12 was further purified by TLC $\left(\mathrm{CHCl}_{3}\right.$ :AcOEt:MeOH, 7:2.5:0.5) to give 12 (5.0 mg). Fraction PGBrMA-21 was subjected to silica gel CC eluting with $\mathrm{CHCl}_{3}: \mathrm{MeOH}$ and increasing the polarity with methanol to obtain 8 subfractions; fraction PGBrMA-21/6 was purified by TLC $\left(\mathrm{CHCl}_{3}: \mathrm{MeOH}, 9: 1\right)$ to give 13 (6.5 mg).

The residue PGLM (15.0 g) was extracted with $\mathrm{CHCl}_{3}$ to obtain the fractions PGLMC (3.9 g) and PGLMM (10.4 g), respectively. The fraction obtained with chloroform had a mixture of hydrocarbons and steroids. The residue from the methanol fraction PGLMM (10.0 g) was chromatographed over silica gel, eluted with $\mathrm{CHCl}_{3}: \mathrm{MeOH}(8: 2)$ as eluent and increasing the polarity until $\mathrm{MeOH} 100 \%$. Eleven fractions were collected. Fraction PGLMM-2 was subjected to silica gel $\mathrm{CC}$ eluting with $\mathrm{CHCl}_{3}: \mathrm{MeOH}(9: 1)$ to obtain 5 fractions, including the PGLMM-2/2-3 with 16 (112.0 $\mathrm{mg}$ ). Fraction PGLMM-2/4 was subjected to silica gel $\mathrm{CC}$ eluting with $\mathrm{CHCl}_{3}: \mathrm{MeOH}(8: 2)$ to afford 6 fractions. Fraction PGLMM-2/4-4 afforded 14 (24.0 mg) and fraction PGLMM-2/4-5 was applied to a Sephadex LH-20 gel column eluting with $\mathrm{CHCl}_{3}: \mathrm{MeOH}(7: 3)$ and furnished 15 (25.0 mg).

The dichlorometane extract from the bark (PGBaD, $4.0 \mathrm{~g}$ ) was fractionated on a silica gel column using hexane as the initial eluent and increasing the polarity with chloroform and methanol until methanol (100\%). Sixty fractions of $25 \mathrm{ml}$ were collected. The solid material obtained from the fractions 7-10 yielded $\mathbf{1}+\mathbf{2}+$ 3 (54.7 mg). Fractions 11-14 yielded a solid 7 (53.4 $\mathrm{mg}$ ). Fractions 23-25 afforded a solid 3a (99.8 mg), and fractions 47-49 were crystallized from methanol to yield the mixture $\mathbf{4}+\mathbf{5}+\mathbf{6}(53.9 \mathrm{mg})$. The extract PGBaM, (70.0 g) was dissolved in methanol:water (8:2) and partitioned with dichlorometane, ethyl acetate and buthanol. The residues PGBaMD (2.0 g), PGBaMA (5.8 g), PGBaMB (4.9 g) and PGBaMM (50.3 g) were obtained from the respective solutions. PGBaMD (1.5 g) was fractionated on a silica gel column using chloroform as the initial eluent and increasing the polarity with methanol until methanol (100\%). Thirty fractions of $25 \mathrm{ml}$ were collected and analyzed by TLC plate. Fractions $15-20(340 \mathrm{mg})$ were submitted to flash silica gel column using hexane and methanol mixture to methanol
$100 \%$. Twenty fractions of $15 \mathrm{ml}$ were collected and analyzed by TLC. Fractions PGBaMD-15-20/3-5 yielded a solid after crystallization from methanol, which was identified as 8 (82.2 mg). Fractions PGBaMD-15-20/912 were crystallized from dimethylketone affording 9 (86.9 mg).

Tri-O-methylvitexin (5,7,4'-trimethoxy-flavone-8C-glucopiranoside, 14a): ${ }^{1} \mathrm{H}$ NMR (200 MHz, DMSOd 6$) \delta_{H}: 8.09\left(\mathrm{~d}, J=8.0 \mathrm{~Hz}, \mathrm{H}-2^{\prime}, 6^{\prime}\right), 7.0(\mathrm{~d}, J=8 \mathrm{~Hz}, \mathrm{H})$, 6.60 (s, 2H, H-3 and H-6), 4.70 (d, $\left.J=10 \mathrm{~Hz}, \mathrm{H}-1^{\prime \prime}\right), 3.92$, 3.88, 3.83 (s, 3H each), 3.9-3.2 (m).

Methyl-gallate (16): ${ }^{1} \mathrm{H}$ NMR (200 MHz, DMSOd ${ }_{6} \delta_{H}: 9.5(\mathrm{HO}), 6.96(\mathrm{~s}, 2 \mathrm{H}), 3.72(\mathrm{~s}, 3 \mathrm{H}) ;{ }^{13} \mathrm{C}-\mathrm{NMR}$ (50.3 MHz, DMSO-d $\left.{ }_{6}\right): \delta_{C} 166.7$ (C-7), 145.9 (C-3,5), 138.8 (C-4), 119.7 (C-1), $108.9(\mathrm{C}-2,6), 51.9\left(\mathrm{OCH}_{3}\right)$; Methyl trimethyl-gallate: ${ }^{1} \mathrm{H}$ NMR (200 MHz, DMSO$\left.\mathrm{d}_{6}\right) \delta_{H}: 7.21(\mathrm{~s}, \mathrm{H}-2,6), 3.82,3.81,3.81,3.72\left(\mathrm{~s}, \mathrm{OCH}_{3}\right.$ $\times 4)$.

\section{RESULTS AND DISCUSSION}

The phytochemical investigation of the extracts from the leaves, branches and bark of Piptadenia gonoacantha allow the identification of four cycloartane triterpenes, cycloartenone (1), cycloartan-25-26-en-3-one (2), 24methylene-cycloartanone (3) and 24-methylenecycloartanol (3a), three steroids, sitosterol (4), campesterol (5), and stigmasterol (6), a saponin, sitosterol-3-O- $\beta$-D-glucopyranoside (4a), three pentaciclic triterpenes, friedelin (7), lupenone (8), and lupeol (9), the N-benzoylphenylalanine-2-benzoylamide-3-phenylpropyl ester (asperphenamate, 10), five flavonoids, apigenin $\left(5,7,4^{\prime}\right.$ trihydroxyflavone, 11), 5-methylapigenin (12), 7, 4' -dihydroxy-3', 5-dimethoxyflavone (13), vitexin (8-C-glucopyranosyl-5, 7, 4' -trihydroxyflavone, 14), and isovitexin (6-C-glucopyranosyl-5,7,4'-trihydroxyflavone, 15), and methyl gallate (16), Figure 2. Their structures were established on the basis of spectral analysis, comparison with literature data and GC-MS analysis of steroids and cycloartenones mixtures.

The identification of compounds 1-3, 3a, 4-6 and 7-9 was achieved by the analysis of IR, NMR and GCEIMS spectra and comparison with literature data. The ${ }^{1} \mathrm{H}$ and ${ }^{13} \mathrm{C}$ NMR spectra and the use of the Olea and Roque methodology, described for the analyses of mixtures (Olea and Roque 1990), allowed the identifica- 
tion of the respective series of 1-3a (cycloartane), 4-6 (steroids) and 7-9 (pentacyclic triterpenes). Detailed analysis of ${ }^{13} \mathrm{C}$ NMR (BBD and DEPT), and comparison with literature data allowed the identification of the cycloartenones (1-3) and 24-methylene cycloartenol 3a (Silva et al. 2005, Davies et al. 1992, Silveira and Pessoa 2005), friedelane (7), lupenes $(\mathbf{8 , 9}$ ) (Davies et al. 1992, Carvalho et al. 1995, Mahato and Kundu 1994) and steroids 4-6 (Dutra et al. 1992, Kojima et al. 1990, Chaurasia and Wichtl 1987). These structures were defined by the GC-MS analysis that allow the identification of three compounds in the fractions group containing the cycloartenones: cycloartenone 1 (Rt 14.29 min, $\mathrm{M}^{+}$. 424), cycloartan-25-26-en-3-one (2: Rt 14.29 $\min , \mathrm{M}^{+}$.424), 24-methylene-cycloartanone (3: Rt 15.61 $\left.\min , \mathrm{M}^{+} .426\right)$; the pure compound 24-methylenecycloartanol (3a, Rt 16.14, $\mathrm{M}^{+}$. 426]; the steroids in mixture: campesterol (5: Rt 13.20 min, $\mathrm{M}^{+}$. 400), sitosterol (4: Rt 14.81, $\mathrm{M}^{+}$. 414) and stigmasterol (6: Rt 16.66 $\min , \mathrm{M}^{+} .412$ ). The glycoside $4 \mathbf{a}$ (sitosterol-3-O- $\beta$-Dglucopyranoside) was identified mainly by ${ }^{1} \mathrm{H}$ and ${ }^{13} \mathrm{C}$ NMR (BBD and DEPT) data analysis and by comparison with literature data (Chaurasia and Wichtl 1987). The number of $\mathrm{C}, \mathrm{CH}, \mathrm{CH}_{2}$ and $\mathrm{CH}_{3}$ and comparison of the values with those from the literature (Olea and Roque 1990, Davies et al. 1992, Carvalho et al. 1995, Mahato and Kundu 1994) for 7-9 allowed to confirm the structure of the triterpenes, friedelin (7), lupenone (8) and lupeol (9).

The ester 10, a solid (MP $184-186^{\circ} \mathrm{C}$ ), was identified by IR, NMR (1D and 2D) and mass spectra analysis. The IR spectrum of $\mathbf{1 0}$ showed absorption bands of $\mathrm{N}-\mathrm{H}\left(v_{\mathrm{NH}} 3310 \mathrm{~cm}^{-1}\right), v_{\mathrm{C}=\mathrm{O}}\left(1750 \mathrm{~cm}^{-1}\right), v_{\mathrm{CO}}(1640$ $\mathrm{cm}^{-1}$ ), besides bands of, $v_{\mathrm{C}-\mathrm{O}}$ and bands characteristics of aromatic rings. The ${ }^{1} \mathrm{H}$ and ${ }^{13} \mathrm{C}$ NMR and $2 \mathrm{D}$ correlated NMR techniques, $\left[{ }^{1} \mathrm{H}^{-1} \mathrm{H}-\mathrm{COSY}\right.$ and ${ }^{1} \mathrm{H}_{-}{ }^{13} \mathrm{C}-$ COSY- ${ }^{\mathrm{n}} J_{C H}(\mathrm{n}=1, \mathrm{HMQC} ; \mathrm{n}=2$ and $3, \mathrm{HMBC})$ ] were used to identify this substance and make the complete proton and carbon- 13 chemical shift assignments. The analysis of ${ }^{1} \mathrm{H} N M R,{ }^{1} \mathrm{H}_{-}{ }^{1} \mathrm{H}-\mathrm{COSY}$ and ${ }^{1} \mathrm{H}_{-}{ }^{13} \mathrm{C}-\mathrm{COSY}-$ ${ }^{1} J_{C H}$ spectra allow the identification of signals of hydrogens in aromatic rings $\left(\delta_{H}\right.$ 7.66-7.15) that were compatible with four mono substituted benzene rings, signals at $\delta_{H}$ 4.85-2.8 of five methylene groups and two metine $\left[\delta_{H} 2.85 / 2.93\left(\mathrm{dd}, 1 \mathrm{H}\right.\right.$ each); $\delta_{H} 3.17 / 3.22(\mathrm{dd}, 1 \mathrm{H}$ each), $\delta_{H} 3.96 / 4.47(\mathrm{dd}, 1 \mathrm{H})$ and $\delta_{H} 4.84(\mathrm{t})$ and 4.53 (m)] connected to carbons $\delta_{\mathrm{CH} 2}: 37.03,37.20,65.41$, and with $\delta_{C H}: 54.50$ and 50.21, respectively. Besides the signals of ${ }^{n} J_{C H}$ detected in HMBC spectrum, the values of hydrogen and carbon-13 chemical shift of $\mathbf{1 0}$ were compared with those of ester described by Catalan et al. (2003), named N-benzoylphenylalanine-2benzoylamide-3-phenylpropyl ester, isolated from $\mathrm{Cro}$ ton hieronymi (Catalan et al. 2003). The mass spectrum shows peaks at $\mathrm{m} / z(\%): 355(10), 328(50), 238(70)$, 146 (100), 118 (60), 91(70) that were used to confirm the structure of 10. This ester was isolated from Zeyhera digitalis (Bignoniaceae) (Faccione et al. 2004), Piper aurantiacatum (Piperaceae) (Banerji and Ray 1981), and Medicargo polymorpha (Leguminosae) (Poi and Adityachoudhury 1986). This compound has been isolated from fungus species, such as Aspergillus flavipes (Clark et al. 1977), Anaphalis subumbellata (Talapatra et al. 1983), Penicillium species (McCorkindale et al. 1978, Bird and Campbell 1982, Nozawa et al. 1989), and it has been named as asperphenamate.

The flavones 11-13 were identified by comparison of these ${ }^{1} \mathrm{H}$ and ${ }^{13} \mathrm{C}$ NMR data (including NOEDIFF experiments of 12 and 13) and mass-spectra, and comparison with literature data. These compounds show positive test for flavonoids using $\mathrm{AlCl}_{3} / \mathrm{EtOH}$ in TLC plate. ${ }^{1} \mathrm{H}$ NMR spectra of flavone 11 show two broad singlets at $\delta_{H}$ $6.44(1 \mathrm{H}), 6.20(1 \mathrm{H})$, one singlet at $\delta_{H} 6.68(1 \mathrm{H})$, two doublets at $\delta_{H} 7.92(J=8.0 \mathrm{~Hz}, 2 \mathrm{H})$, and $6.90(J=8.0$ $\mathrm{Hz}, 2 \mathrm{H})$, besides a singlet at 13.01 of quelated hidroxyl group (5-OH). These data were compared with those of $5,7,4^{\prime}$-trihydroxyflavone and confirmed the structure of $\mathbf{1 1}$ that is known as apigenin (Miyazawa and Hisama 2003). ${ }^{1} \mathrm{H}$ NMR spectrum of $\mathbf{1 2}$ was similar to that one of $\mathbf{1 1}$ only with an additional signal at $\delta_{H} 3.78$ of the methoxyl group. Besides the analysis of ${ }^{13} \mathrm{C} N M R$ and ${ }^{1} \mathrm{H}-{ }^{1} \mathrm{H}-\mathrm{COSY}$ data, the spectra obtained by NOEDIFF experiment show only one signal of NOE $(4 \%)$ at $\delta_{H}$ 6.37 (H-6) by irradiation at $\delta_{C H 3} 3.78$, and $\mathrm{NOE}(14 \%)$ at $\delta_{H} 7.84\left(\mathrm{H}-2^{\prime}, 6^{\prime}\right)$ by irradiation at $\delta_{H} 6.50(\mathrm{H}-3)$. The ${ }^{13} \mathrm{C}$ NMR data were identical to those of 5-O-methylapigenin (Wagner et al. 1976). The spectra of $\mathbf{1 3}$ show signal at $\delta_{H} 6.31$ (brs), 6.47 (brs), 6.57 (s), 7.44 (brs, 2H) and $6.88(\mathrm{~d}, J=8 \mathrm{~Hz}, 1 \mathrm{H})$, and two singlets of $\mathrm{OCH}_{3}$ at $\delta_{C H 3} 3.85$ and 3.75. The same NOE experiments made 
with 12 were made with 13 and allow the identification of NOE at $\delta_{H} 6.31(\mathrm{H}-6)$ and $7.44\left(\mathrm{H}-2^{\prime}\right)$, confirming the methoxyl group at 5 and $3^{\prime}$ positions. These data and analysis of ${ }^{1} \mathrm{H} \times{ }^{1} \mathrm{H}-\mathrm{COSY}$, besides the LREIMS spectrum $[\mathrm{m} / z(\%)$ : $314(1), 180$ (100), 163 (50), 147 (10), 137 (50), 124 (20), 109(10)], allow the identification of 13 as 7,4'-dihydroxy-5,3'-dimethoxyflavone.

The ${ }^{1} \mathrm{H}$ NMR spectrum of flavonoids 14 and $\mathbf{1 5}$ shows signals of a flavone moiety containing four groups: three hydroxyl group and one sugar unit in both $\mathbf{1 4}$ and 15 as indicated by the following signals: 14: $\delta_{H} 8.0$ $(\mathrm{d}, J=8 \mathrm{~Hz}, 2 \mathrm{H}) / 6.88$ (d, $J=8 \mathrm{~Hz}, 2 \mathrm{H})\left(\mathrm{AA}^{\prime} \mathrm{BB}^{\prime}\right.$ system), 6.77 (H-3)/6.26(H-6), 4.68(d, $J=10 \mathrm{~Hz}, 1 \mathrm{H})$, multiplet between 3.8-3.0 and singlet at 13.2; 15 7.90(d, $J=8 \mathrm{~Hz}$, $2 \mathrm{H}) / 6.92(\mathrm{~d}, J=8 \mathrm{~Hz}, 2 \mathrm{H})\left(\mathrm{AA}^{\prime} \mathrm{BB}^{\prime}\right.$ system $), 6.75(\mathrm{H}-$ 3)/6.53(H-8), 4.58(d, $J=10 \mathrm{~Hz}, 1 \mathrm{H})$, multiplet between $\delta_{H}$ 4.5-3.0 and 13.6(s). Comparison of the ${ }^{13} \mathrm{C}-\mathrm{NMR}$ (BBD and DEPT) data showed that all the carbon chemical shifts were similar, but small differences were $\delta_{C H}$ 93.7, $\delta_{C} 79.0,108.5$ in $\mathbf{1 5}$. These data and comparison with ${ }^{1} \mathrm{H}$ and ${ }^{13} \mathrm{C}$ NMR literature data, allow the identification of $\mathbf{1 4}$ as vitexin (Zhou et al. 2005), and 15 as isovitexin (Pedras et al. 2003). NOEDIFF experiments confirmed these identifications. Irradiation of 14 at $\delta_{H O-5}(13.2)$ shows $\mathrm{NOE}$ at $\delta_{H} 6.78(\mathrm{H}-6)$, and irradiation on $\delta_{H-3}$ shows NOE at $\delta_{H} 8.0\left(\mathrm{H}-2^{\prime} .6^{\prime}\right)$. The same experiments were made with 15 and the obtained results were according with its identification as isovitexin. Methylation of $\mathbf{1 4}$ (in methanol) with diazomethane ether solution yielded 14a, which is additional data to confirm the identification of 14 .

The IR, ${ }^{1} \mathrm{H}$ and ${ }^{13} \mathrm{C}$ NMR spectra of 16 were analyzed and compared with literature data to identify this compound as methyl gallate (Scott 1972). The tri-Omethyl derivative obtained by the treatment of $\mathbf{1 6}$ with diazomethane ether solution yielded 16a (see experimental) and confirmed its identification.

\section{ACKNOWLEDGMENTS}

The authors are grateful to Conselho Nacional de Desenvolvimento Científico e Tecnólogico (CNPq), Fundação Carlos Chagas Filho de Amparo à Pesquisa do Estado do Rio de Janeiro (FAPERJ), Coordenação de Aperfeiçoamento de Pessoal de Nível Superior (CAPES) for grants and fellowships, and thank CENAUEMN,
UFC, Fortaleza-CE, Brazil, for the $500 \mathrm{MHz}$ NMR spectra.

\section{RESUMO}

O estudo fitoquímico de galhos de Piptadenia gonoacantha (Mart.) J.F. Macbr. (Leguminosae-Mimosoideae), comumente conhecida como "pau jacaré", forneceu sitosterol, estigmasterol, o éster N-benzoilfenilalaninato de 2-N-benzoil-3-fenilpropila, conhecido como asperfenamato, 3-O- $\beta$-D-glicopiranosil-sitosterol, além de três flavonóides, apigenina $\left(5,7,4^{\prime}\right.$ triidroxiflavona), apigenina-5-O-metil éter e 7,4' -dihidroxi-3', 5-dimetoxiflavona. Das folhas isolaram-se galato de metila e dois flavonóides, 8-C-glicopiranosil-5,7,4' ${ }^{\prime}$-trihidroxiflavona e 6-C-glicopiranosil-5,7,4'-trihidroxiflavona, conhecidas como vitexina e isovitexina. Das cascas desta planta isolaram-se uma mistura de sitosterol, campesterol e estigmasterol; mistura de cicloartenona, cicloartan-25,26-en-3-ona e 24-metileno-cicloartanona, além dos triterpenos, 24-metilenocicloartenol, fridelina, lupeol e lupenona. As estruturas foram estabelecidas através de análise de espectros de IV, $\mathrm{RMN}{ }^{1} \mathrm{He}{ }^{13} \mathrm{C}$ e massas, além de análise com CG-EM para identificar os componentes das misturas de cicloartanos e esteróides. O éster conhecido como asperfenamato, os flavonóides e os cicloartanos estão sendo registrados pela primeira vez em Piptadenia.

Palavras-chave: Leguminoseae, Piptadenia gonoacantha, terpenóides, asperfenamato, flavonóides, pau jacaré.

\section{REFERENCES}

BANERJ A AND RAY R. 1981. Auranamide, a new phenylalanine derivative isolated from Piper aurantiacum Wall. Ind J Chem B 20B: 597-598.

BIRD BA AND CAMPBell LM. 1982. Disposition of mycophenolic, brevianamide A, asperphenamate, and ergosterol in solid cultures of Penicillium brevicompactum. Appl Environ Microbiol 43: 345-348.

Carvalho MG DE, Almeida MEL de, Hauptli MB AND Meleiro LAC. 1995. Triterpenos Isolados de Eschweilera rabelilana Mori (Lecythidaceae). Rev Univ Rural Ser Cienc Ex e da Ter 17(1-2): 33-36.

Catalan CAN, Heluani CS, Kotowicz C, Gedris TE AND HERZ W. 2003. A linear sesterterpene, two squalene derivatives and two peptide derivates from Croton hieronymi. Phytochemistry 64: 625-629.

Chaurasia N ANd Wichtl M. 1987. Sterols and steryl glycosides from Urtica dioica. J Nat Prod 50: 881-885. 
Clark AM, Hufford CD And Robertson LW. 1977. Two metabolites from Aspergillus flavipes. J Nat Prod (Loydia) 40: 146-151.

Correa MP. 1984. Dicionário de plantas úteis do Brasil, e das exóticas cultivadas, Rio de Janeiro, RJ, Editora Ministério da Agricultura, Instituto Brasileiro de Desenvolvimento Florestal, 4329 p.

Davies NW, Miller JM, NAidu R And Sotheeswaran S. 1992. Triterpenoids in bud exudates of Fijian Gardenia species. Phytochemistry 31: 159-162.

Dutra NN, Alves H de M, Carvalho MG DE AND BRAZ-FILHO R. 1992. Constituintes Químicos de Simaba obovata. Quim Nova 15: 10-14.

FACCIONE M, FERrEIRA DT, BRAZ-FiHo R AND POMINI AM. 2004. Synthesis of asperphenamate and aurantiamide benzoate for structural revision. Rev Latinoamer Quim 32: 7-14.

Giesbrecht AM. 1960. Bufotenine occurrence in Piptadenia falcate seeds. An da Assoc Bras de Quim 19: 117-119.

Kojima H, Sato N, Hatano A and Ogura H. 1990. Sterol Glucosides from Prunella vulgaris. Phytochemistry 29: 2351-2355.

LEGLER G AND TSCHESCHER R. 1963. The isolation of $\mathrm{N}$-methyltriptamine, 5-methoxy-N-methyltriptamine and 5-methoxy-N,N-dimethyltryptamine from the bark of Piptadenia peregrine. Naturwissenschaften 50: 94-95.

LorenzI H. 1998. Árvores Brasileiras: Manual de identificação e cultivo de plantas arbóreas nativas do Brasil, $2^{\mathrm{a}}$ ed., Nova Odessa, SP, Editora Plantarum, 357 p.

MAHATO SB AND KUNDU AP. 1994. 13C-NMR spectra of pentacyclic triterpenoids - a compilation and some saliente features. Phytochemistry 37: 1517-1575.

MCCORKINDALE NJ, BAXTER RL, ROY TP, SHIELdS HS, StewART RM AND HutCHINSON SA. 1978. Synthesis and chemistry of N-benzoyl-O-[N'-benzoyl-L-phenylalanyl]-L-phenylalaninol, the major mycelial metabolite of Penicillium canadense. Tetrahedron 34: 2791-2795.

Miyauchi Y, Yoshimoto T And Minami K. 1976. Extractives of hardwood, IX, Extractives from heartwood of Piptadenia sp. Mokuzai gakkaishi 22: 47-50.

Miyazawa M And Hisama M. 2003. Antimutagenic activity of flavonoids from Chysantemum morifolium. Biosc Biotecnol Biochem 67: 2091-2099.

Nascimento IA, Gomes MS, Carvalho MG DE AND Carvalho AG DE. 2003. Deslocamentos químicos de ${ }^{1} \mathrm{H}$ e ${ }^{13} \mathrm{C}$ de 5 -H-flavanona e 5 -H-flavonol isolados de Leguminosae. Rev Univ Rural Ser Cienc Ex e da Ter 22 $(1,2)$ : 81-87.
Nozawa K, Udagawad S, Nakajima S AND Kamai KS. 1989. A dioxopiperazine derivative from Penicillium megasporum. Phytochemistry 28: 929-931.

Olea RSC AND Roque NF. 1990. Análise de Misturas de Triterpenos por RMN de ${ }^{13} \mathrm{C}$. Quim Nova 13: 171-175.

PATCHER IJ, ZACHARIUS DE AND RIBEIRO O. 1959. Índole alkaloids of Acer saccharinum (silver maple), Dictyoloma incanescens, Piptadenia columbrine, and Mimosa hostilitis. J Org Chem 24: 1285-1287.

Pedras MSC, Chumala PB And Suchy M. 2003. Phytoalexins from Thlaspi arvense a wild crucifer resistant virulent Leptosphaeria maculans: structures, syntheses and antifungal activity. Phytochemistry 64: 949-956.

Piacente S, Balderrama L, de Tomassil H, MoraLes L, VARAgas L AND PizA C. 1999. Anadanthoside: a flavanol-3-O- $\beta$-D-xilopyranoside from Anadenanthera macrocarpa. Phytochemistry 51: 709-711.

Poi R ANd AdityachoudhuRY N. 1986. Occurrence of two rare amides in Medicago polymorpha. Ind J Chem B 25B: $1245-1246$.

SCOTT KN. 1972. Carbon-13 nuclear magnetic resonance of biologically important aromatic acids I. Chemical shifts of benzoic acid and derivatives. J Am Chem Soc 29: 85648568 .

Silva MSS, Citó AMGL, Chaves MH And Lopes JAD. 2005. Triterpenos tipo cicloartano de Terezina-PI. Quim Nova 28: 801-804.

Silveira ER AND Pessoa ODL. 2005. Constituintes micromoleculares de plantas do Nordeste com potencial farmacológico: com dados de $\mathrm{RMN}{ }^{13} \mathrm{C}$. Fortaleza expressão Gráfica e Editora, 216 p.

Stromberg VL. 1954. The isolation of bufotenine from Piptadenia peregrina. J Am Chem Soc 76: 1707.

Talapatra SK, Pal JK, Mallik AK and Talapatra B. 1983. Structure and synthesis of (-)-anabellamide. A new phenylalanine derivative ester amide from Anaphlis subumbellata occurrence of 4 '-hydroxydehydrokawain. J Nat Prod 46: 140-143.

Wagner HW, Chari VM ANd Sonnenbichler J. 1976. Carbon-13 NMR spectra of naturally occurring flavonoids. Tetrahedron Lett 21: 1799-1802.

ZHOU X, JinYONG P, FAN G AND WU Y. 2005. Isolation and purification of flavonoid glycosides from Trollius ledebouri using high-speed counter-current chromatographic by stepwise increasing the flow-rate of the mobile phase. J Chromatogr A 1092: 216-221. 